\title{
EVALUATION OF Deutzia x carnea (Lem.) Rehd. AS A FOOD SOURCE TO URBAN BEES
}

\author{
Marzena Masierowska \\ University of Life Sciences in Lublin, Department of Botany, Akademicka 15, 20-950 Lublin, Poland \\ e-mail:mlm25@up.lublin.pl
}

Received: 01.07.2012

\begin{abstract}
This 3-year study examined the flowering phenology, total floral display, nectar and pollen production as well as bee visitation to the ornamental shrub Deutzia $\mathrm{x}$ carnea (Lem.) Rehd.

D. x carnea bloomed from early June until the middle of July. The total flower display reached 47927 flowers per plant. The number of developed flowers strongly depended on weather conditions before and during the flowering period and fluctuated significantly during the years of study. The flower of $D$. x carnea lived 5 days and the persistence of an inflorescence was 11 days.

Nectar productivity per 10 flowers differed significantly between the years of study and ranged between 15.7 and $40.14 \mathrm{mg}$. Mean sugar content in nectar was $39.7 \%$. The total sugar mass in nectar per 10 flowers averaged $9.91 \mathrm{mg}$ (range: $3.81-18.91 \mathrm{mg}$ ). Pollen mass per 10 flowers was $16.89 \mathrm{mg}$. The estimated sugar and pollen productivity per plant was $36.8 \mathrm{~g}$ and $40 \mathrm{~g}$, respectively.

Among bees (Apoidea), honey bees were principal visitors on Deutzia flowers. The peak of daily activity of honey bees and bumblebees occurred between 11.00 and $15.00 \mathrm{hrs}$, whereas the presence of other wild bees was noted in the morning and in the late afternoon. All bees gathered mainly nectar, but pollen collectors were also noted. The mean daily visiting rate was 0.0809 visits per flower $\times \mathrm{min}^{-1}$.

The use of this shrub in gardens and parks should be encouraged in order to enrich food pasture for urban Apoidea. However, its cultivation is limited to areas of mild climate and adequate water supply.
\end{abstract}

Key words: Deutzia x carnea, flowering, nectar, pollen, urban bees

\section{INTRODUCTION}

Bees are important plant pollinators, both in the natural environment and in anthropogenic habitats, e.g. cultivated crops or urban sites. For bees, urbaniza- tion means a change in the availability of refuges and nesting places as well as in the quality and quantity of food plants. However, a city can be a very important habitat for diverse bee species (E r e m e e v a and Sushchev, 2005; B anaszak-Cibicka and Żmichorski, 2012), including managed honey bees. Moreover, plant species richness often increases in urban areas compared to more natural habitats (Grim m et al. 2008), so urban sites are thought to be potential resources for nectar- and pollen-foraging insects (A c a r et al. 2007; De n is ow, 2011). In particular, the presence of garden plants can help sustain all insect pollinators on which plants depend for their pollination. The newly-planted urban parks and gardens are now more often designated for bees and have potential to attract these insects if diverse floral resources are provided throughout the growing season (C o m b a et al. 1999; T o m mas i et al. 2004; Dijkstra and Kwak, 2007; W oj cik et al. 2008; Sperling and Lortie, 2010). Especially, honey bees can profit from them.

The attractiveness of plants for bees is determined by (a) the size of reward (nectar and/or pollen), and (b) the occurrence of mass flowering. Among plants grown in urban landscapes, various ornamental shrubs, including some deutzias, are thought to be valuable food sources for bees (Gozdalik, 1976; Mountain et al. 1981; Riccardelli d'Albore, 1991; Larsson and Shuel, 1992; Masierow sk a, 1999, 2006; Li p i ń s k i , 2010). Deutzias are deciduous or rarely evergreen shrubs indigenous to temperate regions of Asia and mountainous regions of Central America. They were introduced to Europe in the nineteenth century (Zaik on nikova, 1966) and various species and cultivars are recommended as standard ornamental shrubs for landscaping in temperate zones (K r ü s s man n, 1977; R e h d e r, 1997, 
B u g a $\nmid$ a et al. 1984), useful for foundation planting or as a part of a shrub border. Their decorative value derives from their beautiful and numerous flowers.

The estimation of deutzias as food sources for insects is limited to few species and cultivars. In Italy Riccardelli d'Albore (1991) estimated honey production of D. scabra as $400 \mathrm{~kg} \times \mathrm{ha}^{-1}$. In Poland, Go z d a lik (1976) found that one flower of $D$. x magnifica, D. rosea and D. scabra produced daily from 0.5 to $2.8 \mathrm{mg}$ of nectar with a sugar content 12 to $68 \%$ and that the mean total sugar amount in nectar per 10 flowers always exceeded $3 \mathrm{mg}$. According to $\mathrm{M}$ a s i e r ow sk a $(1999,2006)$, the mean amounts of sugars secreted in nectar throughout a lifetime by 10 flowers of $D$. discolor, D. gracilis, D. x magnifica, D. purpurascens, D. scabra and its cultivars as well as D. schneideriana ranged from 8.32 to $18.7 \mathrm{mg}$. The nectar was highly concentrated - from 22.9 to $48.8 \%$, on average. She also found that pollen production in those deutzias was similar and reached $17.8 \mathrm{mg} / 10$ flowers. Gozdalik (1976) described D. scabra, $D$. x magnifica and D. rosea as sources of pollen for visiting insects. According to Mountain et al. (1981), D. scabra and D. x kalmifolia supplied honey bees only with pollen.

Both in natural and urban habitats, Deutzia flowers attract numerous insect visitors from the Hymenoptera, Diptera and Lepidoptera orders. Among them, bees are the most common (In o u e et al. 1990; Kato et al. 1990; Riccardelli d'Albore, 1991; Lars s on and Shue 1, 1992; W a t a n abe, 1998; Masierowska, 1999, 2006; Tai and Iti n o, 2000, P a n et al. 2010).

Deutzias usually do not grow well when planted in regions of harsh climate, especially with low rainfalls. However, Deutzia x carnea (Lem.) Rehd. has been reported as a relative winter hardy shrub, immune to diseases and resistant to drought as well as to pollutions by dust and smoke (M a l y u g i n, 1990).

The aim of this study was: (1) to examine flowering phenology and blooming abundance of this taxon in urban garden conditions; (2) to investigate its floral rewards available to visiting insects; and (3) to monitor the activity and spectrum of bees collecting these rewards. The primary purpose of this investigation was to determine if $D$. x carnea is a valuable source of high quality food for visiting insects, equal to previously investigated deutzias, and thus can enrich bee pasture in urban landscape.

\section{MATERIALS AND METHODS}

\section{Study site, plant species and its flowering biology}

The present study was conducted on four individuals of Deutzia x carnea growing on a loess-de- rived soil in the Botanical Garden of the Maria Skłodowska-Curie University, Lublin, Poland ( $\mathrm{N}-51^{\circ} 09^{\prime}$, E - $\left.22^{\circ} 27^{\prime}\right)$. Deutzia x carnea, a hybrid between D. gracilis and D. sieboldiana, is a shrub to $1 \mathrm{~m}$ high with brown bracts and ovate to oblong-ovate, $3-5 \mathrm{~cm}$ long leaves. Flowers are nearly $2 \mathrm{~cm}$ across, white inside and pink outside. Sepals are deltoid, purplish; stamens about as long as the style, the filaments with short teeth. Flowers are arranged in loose, upright panicles.

Observations on flowering biology necessary for estimating the nectar and pollen flow were conducted during the 3-year study. The study on the phenology of flowering was carried out at the species level as well as at the inflorescence and flower levels ( $\mathrm{D}$ a f n i , 1992). Flowering onset and length of blooming period were recorded. The length of flowering of a single inflorescence was determined, too. Floral persistence was counted as the days from the opening to the fall of all petals. The total number of flowers per plant was determined by counting the number of inflorescences that developed during the flowering period on each plant and the mean number of flowers in an inflorescence for a particular shrub.

\section{Floral nectaries}

Investigations of the structure of the nectaries in deutzia flowers were conducted using LM and SEM. In glycerol-mounted slides hand-cut from fresh material, the diameter as well as the thickness of the secretory ring were measured $(\mathrm{n}=50)$ using light microscopy (LM). For SEM, the nectaries were fixed in buffered 4\% glutaraldehyde for 4 hours, washed, dehydrated in an ethanol sequence and then transferred into acetone. Next, the samples were dried in $\mathrm{CO}_{2}$ at the critical point and coated with gold using a CS Sputter Coater. The surface of the secretory ring was examined under a BS 340 Tesla scanning electron microscope.

\section{Floral reward measure}

To determine nectar productivity, flower buds were isolated in the field and nectar secreted throughout the lifetime of an individual flower was collected in 2003-2005 seasons. Nectar amount (in mg) was gathered and measured using Jabłoński's pipettes. A total of 25 samples were collected during this study. Each sample contained nectar from 5 to 10 flowers. Nectar sugar content $(\% \mathrm{wt} / \mathrm{wt})$ was measured with an Abbe refractometer. Then, nectar amount and sugar content of nectar were used to calculate the total sugar amount (in $\mathrm{mg}$ ) secreted in nectar per 10 flowers. The nectar productivity was expressed as grams of secreted sugars per plant.

The pollen mass available to insects was determined by the ether method (W a r a k o m s k a, 1972). Six samples of 100 mature anthers were collected each year. Pollen production was expressed in mg per 100 anthers $=10$ flowers and in $g$ per plant. 


\section{Insect visitation}

Throughout the peak blooming period, bee foraging activity on $D$. x carnea flowers was monitored. The number of open flowers and then the number of working insects in a field of view $\left(0.25 \mathrm{~m}^{2}\right)$ were counted for 5 minutes, three times every 2 hours, from $9.00 \mathrm{~h}$ to $17.00 \mathrm{~h}(\mathrm{GMT}+2 \mathrm{~h})$. This procedure was performed 3 to 4 times during each year of the study. The counts were converted to the visiting rate (visits per flower $\times \mathrm{h}^{-1}$ ) according to M a y field et al. (2001). Observations discriminated three bee categories: honey bees, bumblebees and other wild bees, mainly solitary bees. Relative abundance and daily visitation pattern of these categories were determined.

\section{Data analysis}

Whenever possible, parametric statistical analysis was used on the variables by applying standard analysis of variance procedures. When significant differences were found, the ANOVAs were followed by the HSD Tukey test at $=0.05$ ( $\mathrm{S} \mathrm{tan} \mathrm{i} \mathrm{s} \mathrm{z,} \mathrm{2006).}$ Descriptive statistics were calculated and are presented as the means $\pm \mathrm{SD}$. Data in the figures are presented as the average values.

The differences in the nectar amount, nectar sugar content, total sugar amount in nectar and the amount of pollen per 10 flowers between years of study were tested by means of one-way ANOVAs. Non-normally distributed data, the number of flowers/inflorescence, number of inflorescences/plant, total flower number/plant and the life-span of a flower and of an inflorescence were subjected to Kruskal-Wallis ANO$\mathrm{VA}$ and $\mathrm{H}$-test for nonparametric data. Data analyses were performed with STATISTICA v. 7.1 (StatSoft Poland, Krakow).

\section{RESULTS}

\section{Blooming phenology and floral display}

Under the climatic conditions of eastern Poland during the 2003-2005 seasons, the blooming of the studied species lasted from early June to the middle of July -4 weeks on average. The detailed dates of the seasonal flowering period are shown in Table 1 . The time of blooming differed among the years of the study and was affected by weather conditions (Tables 1 and 2). Generally, flowering was facilitated by good temperature and moisture conditions both during the flowering period and in the period preceding it. The warm springs in 2003 and 2004 sped up the blooming of deutzia and also promoted flower formation. Low temperatures in spring 2005 negatively affected the formation and development of $D$. x carnea flowers. The detailed data concerning blooming abundance of the studied species are shown in Table 3. The influence of the growing se- ason on the number of flowers formed per inflorescence as well as on the number of inflorescences per plant and the total number of flowers per plant was significant (Table 3).

The life-span of a single flower was $\sim 5$ days, while a single inflorescence persisted 11 days, on average (Table 2 ).

\section{Floral nectary and nectar production}

In the flowers of $D . \mathrm{x}$ carnea, the secretory tissue formed an orange narrow collar or ring atop of the ovary (Fig. 1a). This ring was located just inside the stamen whorl and was not contiguous with the bases of the styles. The mean outer diameter of the ring was 5.04 $\pm 0.79 \mathrm{~mm}$ (range: $3.7-5.9$ ), whereas the thickness averaged $507 \pm 115 \mu \mathrm{m}$ (range: 238-869). The nectary surface was covered by dense epidermal papillae (Fig. 1b, c). A striated cuticle was visible on the papilla surface. Among these papillae, nectar-releasing stomata were hidden (Fig. 1d). The positioning of nectarstomata was indicated by numerous hollows on the nectary surface (Fig. 1b).

Nectar secretion started just after flower buds opened and continued until the anthers were empty of pollen. It lasted $\sim 4$ days. All characteristics of nectar production in the flowers of $D$. x carnea, i.e. the nectar amount, sugar content of nectar and total sugar mass in nectar, demonstrated a significant year effect (Table 4). The detailed data concerning these features are shown in Table 5. Nectar secretion was most abundant in 2003 - the season with weather conditions also favourable for flower formation. The amounts of nectar produced in 2004 and 2005 were $2.6 \times$ and $2 \times$ lower, respectively. Mean sugar content in nectar ranged from 26.2 to $49.9 \%$. The total sugar mass secreted in nectar was the highest in 2003 and the lowest in 2004. The values of nectar production obtained in 2005 - the season with the lowest number of flowers developed per plant - were generally higher when compared to those obtained in 2004. This may indicate a compensation effect. Plants having little developed flowers could spend more sugars for nectar production. The estimated total sugar mass per plant depended both on the abundance of flowering and sugar productivity of flowers, and ranged from 2.47 to $97.42 \mathrm{~g}$ (Fig. 2).

\section{Pollen production}

In the flowers of $D . \times$ carnea, all ten stamens were functional. However, the mass of pollen produced in anthers differed significantly between years of study (Tables 4 and 5). The highest values were obtained in 2005, the lowest ones in 2004. Variation within species in the amount of pollen produced by the same number of anthers can be caused by differences in anther size, the development of archespore tissue, and by the percentage of non-fertile pollen grains, which can 
vary from year to year. The mean estimated pollen productivity of a single shrub was $40 \mathrm{~g}$ (Fig. 2).

\section{Bee visitation}

Deutzia x carnea flowers attracted numerous bees. The visitor assemblage was stable during the years of observations. The principal visitors were honey bees (Fig. 3a). Among wild bees, bumble bees were most abundant. Under good weather conditions, bees foraged on flowers throughout the day with peak activity between 11.00 and $15.00 \mathrm{~h}$. The daily visitation patterns of various groups of bees on Deutzia flowers are shown in Figure 3b. Honey bees and bumblebees were present continuously during all day, whereas the other bees - mainly Andrena ssp. and Evylaeus ssp. - remained active on deutzia flowers in the morning and they appeared again in late afternoon. The main daily visiting rate for all bees was 0.0809 visits per flower $\times \mathrm{h}^{-1}$. The daily values for Apis mellifera, Bombus spp. and other wild bees averaged $0.0598,0.018$, and 0.0031 , respectively. The bees gathered mainly nectar, but pollen collectors were also observed.
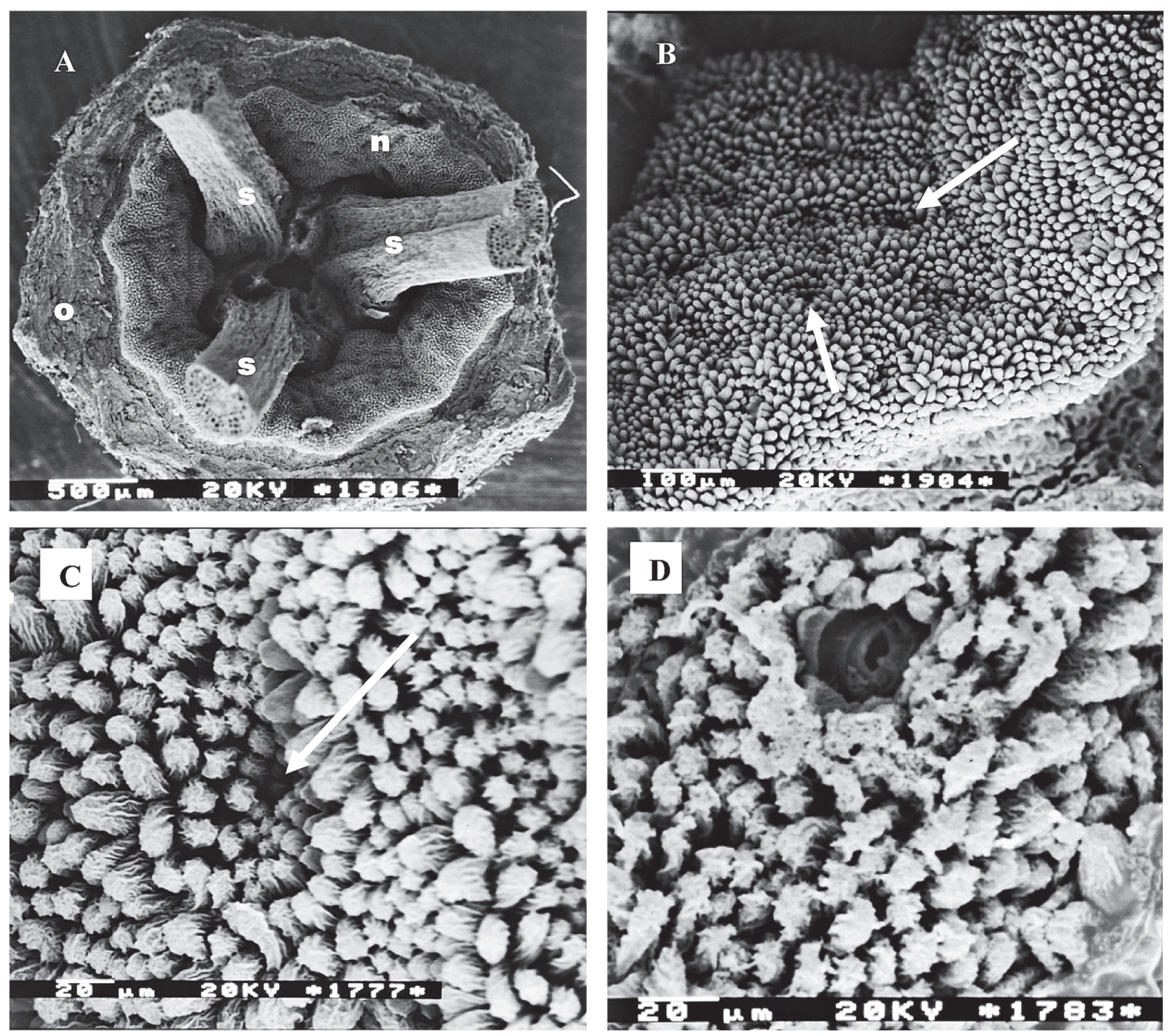

Fig. 1. The nectary of Deutzia x carnea (electron micrographs SEM). A. The nectary ring (n) placed atop the inferior ovary (o) and encircling three styles (s). B. The nectary surface is covered by dense papillae and shows numerous hollows (arrows) that indicate the positions of the stomata. $\mathbf{C}$. The striated cuticle on the surface of the papillae. D. A nectarostoma hidden at the bottom of the hollow. 
Table 1

Dates of flowering and length of flowering period of Deutzia $\mathrm{x}$ carnea during the years 2003-2005

\begin{tabular}{ccc}
\hline Year & Flowering period & Length of flowering period (in days) \\
\hline 2003 & 5 June - 29 June & 25 \\
2004 & 19 June - 12 July & 30 \\
2005 & 15 June - 9 July & 24 \\
\hline
\end{tabular}

Table 2

Monthly and long-term means of air temperature and total precipitation in the Lublin area during the flowering period of D. x carnea and the period proceeding it during the years of the study

\begin{tabular}{|c|c|c|c|c|c|}
\hline \multirow[t]{2}{*}{ Year } & \multicolumn{5}{|c|}{ Month } \\
\hline & III & IV & V & VI & VII \\
\hline \multicolumn{6}{|c|}{ Temperature in ${ }^{\circ} \mathrm{C}$} \\
\hline 2003 & 1.6 & 6.5 & 16.3 & 17.4 & 19.8 \\
\hline 2004 & 2.8 & 7.9 & 11.9 & 15.8 & 18.1 \\
\hline 2005 & -0.1 & 9.1 & 13.2 & 16.0 & 19.8 \\
\hline $\begin{array}{l}\text { Long-term mean } \\
1951-2000\end{array}$ & 1.0 & 7.5 & 13.0 & 16.5 & 17.9 \\
\hline \multicolumn{6}{|c|}{ Precipitation in $\mathrm{mm}$} \\
\hline 2003 & 6.6 & 40.7 & 71.4 & 39.6 & 98.1 \\
\hline 2004 & 33.9 & 38.1 & 38.0 & 49.9 & 90.5 \\
\hline 2005 & 48.0 & 18.6 & 96.0 & 55.8 & 109.8 \\
\hline $\begin{array}{l}\text { Long-term mean } \\
1951-2000\end{array}$ & 25.8 & 40.6 & 58.3 & 65.8 & 78.0 \\
\hline
\end{tabular}

Table 3

The year effect on abundance of flowering and persistence of flowers and inflorescences in $D . x$ carnea studied in the years 2003-2005. Values are means \pm S.D. (n)

\begin{tabular}{|c|c|c|c|c|}
\hline Variable & 2003 & 2004 & 2005 & $\begin{array}{l}\text { Anova }{ }^{1} \\
\text { df, } \mathrm{H}, \mathrm{P}\end{array}$ \\
\hline Number of flowers per inflorescence & $\begin{array}{c}24.5 \pm 13.7 \mathrm{a} \\
(117)\end{array}$ & $\begin{array}{c}21.5 \pm 9.4 \mathrm{a} \\
(120)\end{array}$ & $\begin{array}{c}10.0 \pm 7.1 \mathrm{~b} \\
(110)\end{array}$ & $2,132.06,0.000 * *$ \\
\hline Number of inflorescences per plant & $\begin{array}{c}1641.5 \pm 481.8 \mathrm{a} \\
(4)\end{array}$ & $\begin{array}{c}745.5 \pm 285.9 \mathrm{ab} \\
(4)\end{array}$ & $\begin{array}{c}189.3 \pm 58.9 \mathrm{a} \\
(4)\end{array}$ & $2,6.04,0.0488^{*}$ \\
\hline Number of flowers per plant & $\begin{array}{c}47926.7 \pm 29931.9 \mathrm{a} \\
(4)\end{array}$ & $21288.1 \pm 19357.6 \mathrm{a}$ & $\begin{array}{c}3081.3 \pm 2787.1 \mathrm{~b} \\
(4)\end{array}$ & $2,6.08,0.0478^{*}$ \\
\hline Lifetime of a single flower (days) & $\begin{array}{l}4.8 \pm 0.6 \\
\quad(11)\end{array}$ & $\begin{array}{l}5.0 \pm 0.96 \\
\quad(12)\end{array}$ & $\begin{array}{l}4.8 \pm 1.1 \\
(9)\end{array}$ & $\begin{array}{l}2,0.25 \\
0.881 \mathrm{~ns}\end{array}$ \\
\hline Lifetime of an inflorescence (days) & $\begin{array}{c}10.1 \pm 3.8 \\
\quad(11)\end{array}$ & $\begin{array}{c}11.2 \pm 3.99 \\
(12)\end{array}$ & $\begin{array}{c}10.9 \pm 1.5 \\
(12)\end{array}$ & $\begin{array}{l}2,2.94 \\
0.230 \mathrm{~ns}\end{array}$ \\
\hline
\end{tabular}

Statistical differences are noted: $* \mathrm{P}<0.05, * * \mathrm{P}<0.01, \mathrm{~ns} \mathrm{P}>0.05$. Means with the same letter within a row are significantly different at $=0.05 .{ }^{1}$ The Kruskal-Wallis Anova was used. 


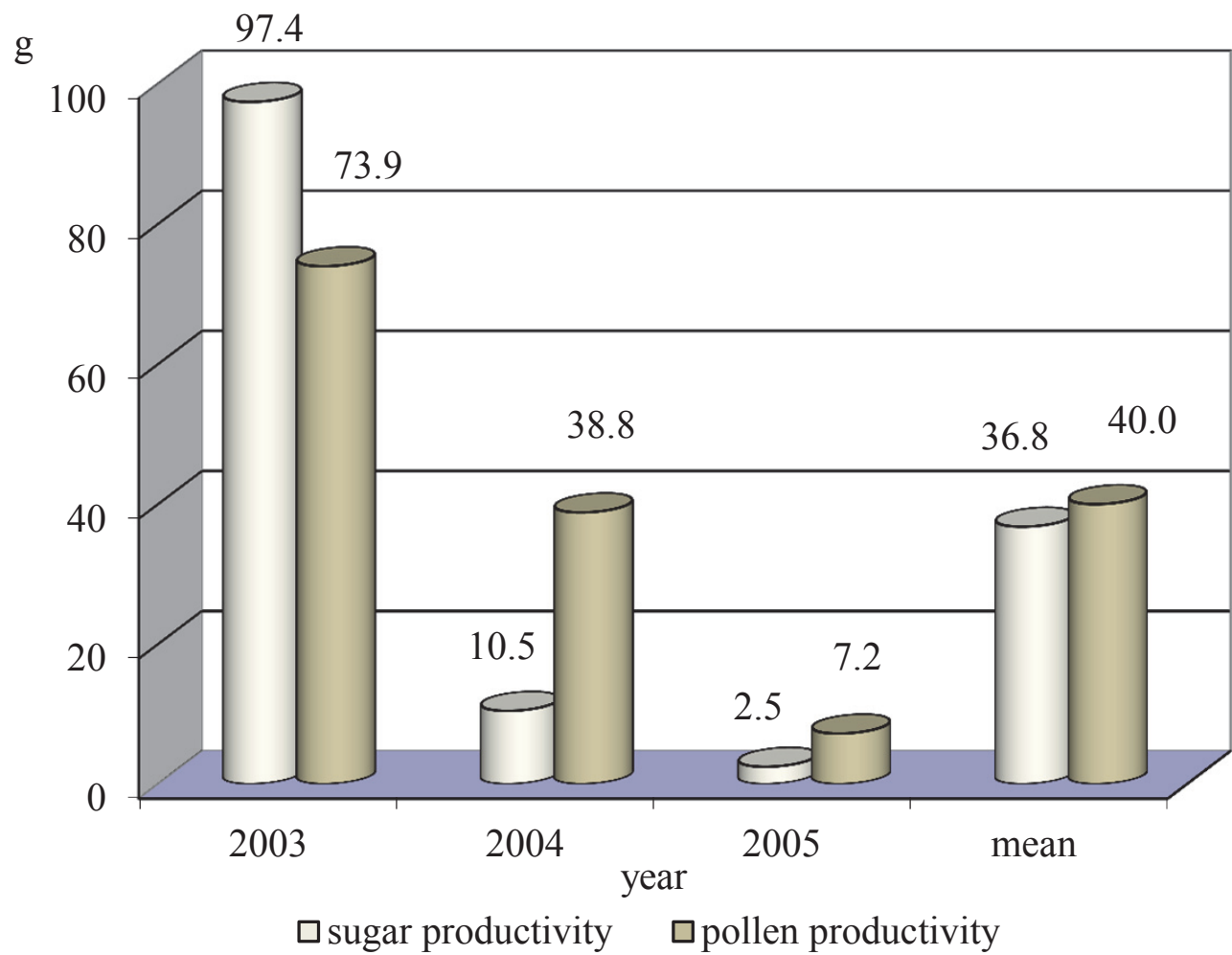

Fig. 2. Estimated mean sugar and pollen productivity (g) of a single shrub of Deutzia $\mathrm{x}$ carnea in 2003-2005 $(\mathrm{n}=4)$

Table 4

ANOVAs of the year effect on nectar and pollen productivity in $D . \mathrm{x}$ carnea during the years of the study

\begin{tabular}{cccccccccc}
\hline Variable & df & \multicolumn{2}{c}{$\begin{array}{c}\text { Nectar amount } \\
\text { per 10 flowers }\end{array}$} & \multicolumn{2}{c}{$\begin{array}{c}\text { Sugar content } \\
\text { of nectar }\end{array}$} & $\begin{array}{c}\text { Total sugar mass per } \\
\text { 10 flowers }\end{array}$ & $\begin{array}{c}\text { Pollen mass per 100 } \\
\text { anthers (10 flowers) }\end{array}$ \\
\hline & & MS & F & MS & F & MS & F & MS & F \\
\hline Year & 2 & 1318.1 & $17.7^{* *}$ & 1527.5 & $14.49^{* *}$ & 469.8 & $31.8^{* *}$ & 50.7 & $4.7^{*}$ \\
\hline Error & 22 & 74.7 & & 105.4 & & 14.8 & & & $10.8^{1}$ \\
& $15^{1}$ & & & & & & & & \\
\hline
\end{tabular}

Significant effect: $* \mathrm{P}<0.05, * * \mathrm{P}<0.001 ;{ }^{1}$ values for pollen mass

Table 5

Amount of nectar (mg), sugar content of nectar (\% wt/total wt), total sugar mass in nectar (mg), and pollen mass per 10 flowers (100 anthers) in $\mathrm{mg}$ in $D$. x carnea flowers during the years 2003-2005. Values are means \pm S.D

\begin{tabular}{cccccc}
\hline Year & $\begin{array}{c}\text { No. } \\
\text { of samples }\end{array}$ & $\begin{array}{c}\text { Nectar amount } \\
\text { per 10 flowers }\end{array}$ & $\begin{array}{c}\text { Sugar content } \\
\text { of nectar }\end{array}$ & $\begin{array}{c}\text { Total sugar mass } \\
\text { per 10 flowers }\end{array}$ & $\begin{array}{c}\text { Pollen mass per 10 } \\
\text { flowers (100 anthers) }\end{array}$ \\
\hline 2003 & $7(6)^{1}$ & $40.14 \pm 11.87 \mathrm{a}$ & $47.17 \pm 4.61 \mathrm{a}$ & $18.91 \pm 6.19 \mathrm{a}$ & $16.52 \pm 3.5 \mathrm{ab}$ \\
2004 & $10(6)$ & $15.70 \pm 5.34 \mathrm{~b}$ & $26.18 \pm 13.19 \mathrm{~b}$ & $3.81 \pm 1.56 \mathrm{c}$ & $14.18 \pm 2.45 \mathrm{~b}$ \\
2005 & $8(6)$ & $20.07 \pm 8.81 \mathrm{~b}$ & $49.92 \pm 9.46 \mathrm{a}$ & $9.67 \pm 3.24 \mathrm{~b}$ & $19.96 \pm 3.78 \mathrm{a}$ \\
\hline mean & $25(18)$ & $23.94 \pm 13.36$ & $39.66 \pm 14.96$ & $9.91 \pm 7.26$ & $16.89 \pm 3.94$ \\
\hline
\end{tabular}

Means within columns with the same letters are not significantly different at $=0.05$. The HSD Tukey test was used. ${ }^{1}$ in parenthesis the number of pollen samples are given. 
a) Realtive abundance of different groups of bees

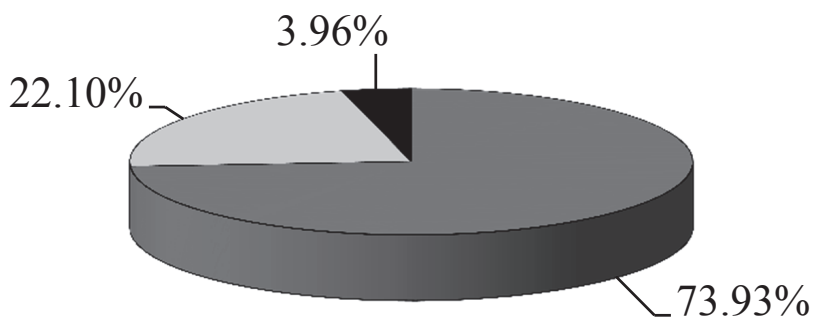

b) Rates of insect visitation to flowers

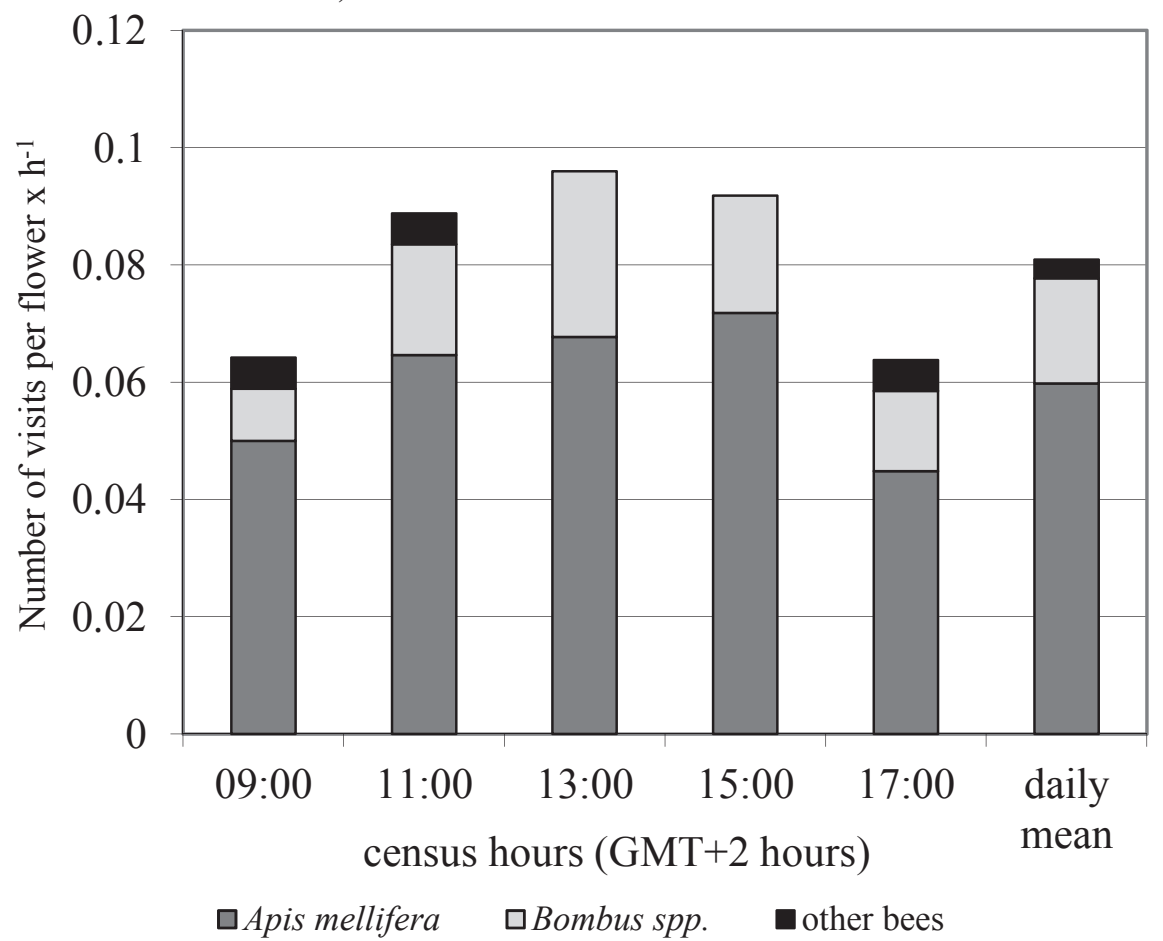

Fig. 3 Insect visitation to Deutzia x carnea flowers (mean values for 2003-2005).

\section{DISCUSSION}

In the environmental conditions of central Europe, deutzias are early to midsummer long-flowering shrubs. Blooming of $D$. x carnea is usually reported from May until June (B i a ł o b o k, 1955; B u g a ł a, 1979; R e h d e r, 1997). In the present study, the flowering period of this species started in June and terminated after 4 weeks, before the middle of July. The differences in the time of flowering can be caused by environmental conditions, differences among genotypes, or phenotypic plasticity ( $\mathrm{R}$ ath cke and L a c e y, 1985; Elzing a et al. 2007). June flowering plants cover what bee keepers call the "June Gap" this is when spring flowering hedges and trees have finished blooming and the summer flowers have not yet started, thus causing a shortage of food for bees.

Deutzia x carnea formed numerous and long-lived flowers, as was previously described for deutzia species or cultivars by many dendrologists (e.g. Z a i k o n n i k o va, 1966, Kr ü s s m a n n, 1997). The studied taxon produced 24099 flowers per plant, on average, the value comparable to that reported for $D$. scabra 'Candidissima' - one of the most valuable deutzia cultivars (M a s i e r o w s k a , 2006). However, significant differences between the years of study for the number of flowers/inflorescence, the number of inflorescences/ plant as well as for the total number of flowers/plant were found. Abundance of blooming may be influenced by weather conditions throughout the growing period, as was observed during this study. The present data show the low resistance of $D$. x carnea flower buds to spring frosts, similar to that found in the other deutzias (O s trow ska, 1981; M a si e row ska, 1999, 2006). The lifespan of a single flower was like those of D. discolor, D. schneideriana, and D. purpurascens (Mas i e rowska, 1999, 2006). The persistence of flowers and inflorescences as well as abundant flowe- 
ring are very valuable features of ornamental plants increasing their attractiveness and being beneficial for their relationships with visiting insects, including bees.

Flowers of $D . \times$ carnea offer to insects both nectar and pollen. Nevertheless, nectar is the main reward collected by them. In the flowers of this taxon, the secretory tissue forms a predominant narrow collar or ring atop the ovary, which can be classified as the structural or ovarian type of nectary (B e r n a r d e l$10,2007)$. A more or less developed nectariferous ring was reported earlier in deutzia flowers (P a $1 \mathrm{~m}$ a t i e $r$, 1943; B e n sel and Palser, 1975). However, the present detailed study revealed that nectar was exuded not through the cuticle of the nectary epidermis, as had been previously described (M a s i e r o w s k a, 2006), but by the "nectarostomata". These stomata are located in deep depressions among the dense papillae covering the nectary surface. Similar positioning of nectar-modified stomata was found in Tropaeolum majus and Fatsia japonica (N e p i , 2007). The arrangement of the floral parts in $D$. x carnea flowers makes nectar easily accessible, mainly for various bees.

The mean nectar mass produced by a flower during 4 days of secretion averaged $2.39 \mathrm{mg}$. This value is comparable with the amounts reported for $D$. scabra and $D \times$ magnifica but lower than those obtained for $D$. discolor, D. gracilis (parental species of D. x carnea) or cultivars of D. scabra (Gozdalik, 1976; $\mathrm{M}$ a si e row ska, 2006). The sugar content in nectar was high - as previously described for deutzias by Gozdalik (1976) and Masierowska (1999, 2006). According to B a n a s zak (1993), bees prefer nectar with sugar content of approx. 50\% and they do not collect nectar if the sugar concentration decreases below $5 \%$. The quantities of nectar-sugar from 10 flowers of the studied taxon were in the range of the values found in D. schneideriana, D. purpurascens and D. scabra (M a s i e row s k a, 1999, 2006). Overall, sugar productivity of $D$. x carnea flowers was not very high. Only in 2003 the daily mass of sugars secreted in nectar per 10 flowers exceeded $3 \mathrm{mg}$ as was obtained for other Deutzia species and cultivars by $\mathrm{G} \mathrm{o} \mathrm{z} \mathrm{d} \mathrm{a} 1 \mathrm{i} \mathrm{k}$ (1976) and M a s i e r o w s k a (2006). The nectar amount as well as sugar concentration in nectar and hence the total sugar mass in nectar differed considerably between growing seasons. It is well known that the quantity and quality of nectar production are determined by the genotype, but they can be environmentally influenced traits depending on microclimate (specifically air temperature, relative humidity, and sunlight), soil type and moisture (S h u e 1, 1955; C o r b e t, 1978; M o h r and J a y , 1990). In deutzias, shrubs with low tolerance of cold and drought, such influence was evident.

In the present study, both nectar- and pollen-collecting bees were observed foraging on deutzia. The pollen output from 10 flowers of $D$. x carnea was high and comparable with pollen productivity of 10 flowers of D. discolor, D. gracilis, D. x magnifica, D. schneideriana and $D$. purpurascens as well as D. scabra and its cultivar 'Watereri' (M a s i e r o w s ka, 1999, 2006). Amounts of pollen produced by anthers and flowers of the recently studied taxon varied between the years of investigation. According to W a r a k o m s k a (1972), the amount of pollen produced by a given number of flowers depends not only on the number of anthers in the flower but also on the size of pollen sacs. The size is correlated with the mass of archesporium, which is influenced by weather conditions during the formation of flower buds, as well as by habitat conditions and soil characteristics (A n d ri e j e v, 1926). Rainfall deficit reduces pollen production in flowers of woody plant species (S z k la n ow s k a, 1992).

Due to abundant flowering, estimated sugar productivity of $D$. x carnea plant was high and similar to that of D. scabra 'Candidissima' - a valuable bee plant. Estimated pollen productivity per plant exceeded the values reported for the above-mentioned deutzia species, but it was $1.8 \times$ lower than that of the cultivar 'Watereri' - the best source of nectar and pollen among deutzias.

Insects, mainly bees, readily foraged on the observed flowers. The predominant visitors were honey bees as was previously reported on deutzia shrubs (e.g. Ostrowska, 1981; Ricciardelli d'Albore, 1991; Lars s on and Shue 1, 1992; P a n et al. 2010). Other common visitors were bumblebees. According to R u s zk ow s ki (1969) as well as R u s z kowski and Biliński (1968), the main species observed on deutzia flowers in Poland are Bombus pascuorum and $B$. hypnorum. Solitary bees, primarily Andrena ssp. and Evylaeus ssp., were present on deutzias, too. In natural habitats in Japan, Deutzia plants are regularly visited by solitary bees from the Halictidae and Andrenidae families (In o u e et al. 1990; K a to et al. 1990). In south-western Japan an oligolectic deutzia andrenid bee (Andrena prostimias) occurs widely (W a t a n a b e, 1998). According to P a n et al. (2010), pollen grains of Deuzia are a starch type. The presence of starch in pollen may be a significant source of energy for wild solitary bees (D e n i s o w, 2011). The mean daily number of visits per flower $x$ $\mathrm{min}^{-1}$ for $D$. x carnea was similar to that for $D$. scabra 'Watereri', the cultivar very eagerly visited by bees. Bee visit frequency changed over the course of the day. The pattern of daily activity of flower visitors was associated with the availability of floral rewards.

\section{CONCLUSIONS}

Deutzia x carnea exhibits several floral traits beneficial for urban bees, including flowering time, abundant floral display, and floral rewards. In the 
course of this study, these shrubs were observed to be a valuable source of nectar and pollen flow during early and midsummer but only under favourable weather conditions, i.e. mild temperatures and adequate rainfall. The previously reported resistance of this taxon to drought and low temperatures has not been confirmed. Planting $D$. x carnea to enrich food pasture for A. mellifera and wild Apoidea is recommended only for regions with a suitably mild climate.

\section{Acknowledgements}

Research supported by the Ministry of Science and Higher Education of Poland as part of the statutory activities of the Department of Botany, University of Life Sciences in Lublin.

\section{REFERENCES}

Acar C., Acar H., Engin E. 2007. Evaluation of ornamental plant resources to urban biodiversity and cultural changing: A case study of residential landscapes in Trabzon city (Turkey). Building and Environment, 42: 218229. http://dx.doi.org/10.1016/j.buildenv.2005.08.030

Andriejev W.N. 1926. Pylca rastienij sobirajemaja pčełami (k metodikie izučenija piergi). Charkov, 51 pp. (in Russian)

B a n a s zak J. 1993. Ekologia pszczół. PWN, Warsaw: 127137. (in Polish)

Banaszak-Cibacka W., Żmihorski M. 2012. Wild bees along an urban gradient: winners and losers. J. Insect Conserv. 16: 331-343. http://dx.doi.org/10.1007/ s10841-011-9419-2

Bensel C.R., Palser B.F. 1975. Floral anatomy in the Saxifragaceae sensu lato. III. Kirengeshomoideae, Hydrangoideae and Escallonioideae. Am. J.Bot. 62 (7): 676-687.

Bernarde11o G. 2007. A systematic survey of floral nectaries. [In]: S.W. Nicolson, M. Nepi, E. Pacini (Eds). Nectaries and Nectar. Springer: 19-128.

Białobok S. 1955. Drzewoznawstwo. PWRiL, Warsaw: 257-263. (in Polish)

Bojarczuk T., Bugała W.; Chylarecki H. 1980. Zrejonizowany dobór drzew i krzewów do uprawy w Polsce. / Regionalization of tree and shrub selection for cultivation in Poland. Arboretum Kórnickie, 25: 329373. (in Polish)

Bugała W. 1979. Drzewa i krzewy dla terenów zieleni. PWRiL, Warsaw: 372-378. (in Polish)

Bugała W., Chylarecki H., Bojarczuk T. 1984. Dobór drzew i krzewów do obsadzania ulic i placów miast z uwzględnieniem kryteriów rejonizacji. / Trees and shrubs for planting of streets and squares in towns, including regionalization criteria. Arboretum Kórnickie, 19: 35-62. (in Polish)

Comba L., Corbet S.A., Hunt L., Warren B. 1999. Flowers, nectar and insect visits: evaluating British plant species for pollinator-friendly garden.
Ann. Bot. 83: 369-383. http://dx.doi.org/10.1006/anbo. 1998.0835

Corbet S. 1978. Bee visits and the nectar of Echium vulgare L. and Sinapis alba L. Ecol. Entom. 3: 25-37. http:// dx.doi.org/10.1111/j.1365-2311.1978.tb00900.x

Dafni A. 1992. Pollination ecology. Oxford Univ. Press: $127-163$.

Denisow B. 2011. Pollen production of selected ruderal plant species in the Lublin area. WUP Lublin, $86 \mathrm{pp}$.

Dijkstra J.P., Kwak M.M. 2007. A meta-analysis on the pollination service of the honey bee (Apis mellifera L.) for the Dutch flora. Proc. Neth. Entomol. Soc. Meet. 18: 79-87.

Elzinga J.A., Alan A., Biere A., Gigord L., Weis A.E., Bernasconi G. 2007. Time after time: flowering phenology and biotic interactions. Trends Ecol. Evol. 22: 432-439.

Eremeeva N.I., Sushev D.V. 2005. Structural changes in the fauna of pollinating insects in urban landscapes. Russ. J. Ecol. 36(4): 259-265.

Gozdalik B. 1976. Ozdobne krzewy z rodzaju Deutzia także nektarodajne. / Ornamental Deutzia shrubs - also a source of nectar. Pszczelarstwo, 11: 4-5. (in Polish)

Grimm N.B., Faeth S.H., Gołubiewski N.E., Redman C.L., Wuj., Bai X., Briggs J.M. 2008. Global change and the ecology of cities. Science, 319: 756-760. http://dx.doi.org/10.1126/science. 1150195

Inoue T., Kato M.; Kakutani T., Suka T., Itin o T. 1990. Insect-flower relationship in the temperate deciduous forest of Kibune, Kyoto: an overview of the flowering phenology and the seasonal pattern of insect visits. Contribution from the Biological Laboratory, Kyoto University, 27(4): 377-463.

Kato M., Kakutani T., Inoue T., Itino T. 1990. Insect-flower relationship in the primary beech forest of Ashu, Kyoto: an overview of the flowering phenology and the seasonal pattern of insect visits. Contribution from the Biological Laboratory, Kyoto University, 27(4): 309-375.

Kr üs s m a n n G. 1977. Handbuch der Laubgeholze. Band I A+D. Parey, Berlin - Hamburg: 465-473. (in German)

Lars on H.C., Shuel R. 1992. Nectar trees, shrubs and herbs of Ontario. Ministry of Agriculture and Food, Ontario, Canada: 10.

Li pi ń s k i M.2010. Pożytki pszczele.Zapylanieimiododajność roślin / Honey bee food sources. Pollination and melliferous value of plants. $4^{\text {th }}$ edition. Z. Koltowski (ed.). PWRiL, Warszawa and Sądecki Bartnik Press, Stróże: 252-344. (in Polish)

Ma ly ug in I.E. 1990. Introduction and prospects for utilizing species of genus Deutzia for ornamental purposes in the Donbass. J. Biulletin Głavnono Botaničeskovo Sada, 158: 28-32.

Masierowska M. 1999. Żylistek Schneidera (Deutzia Schneideriana Rehd.) i żylistek purpurowy (Deutzia purpurescens Rehd.) - biologia kwitnienia oraz wartość pożytkowa dla owadów zapylających. / Flowering 
biology and food value for pollinating insects of Deutzia Schneideriana Rehd. and Deutzia purpurescens Rehd. Bibl. Frag. Agronom. 6: 161-167. (in Polish)

Masierowska M. 2006. Floral reward and insect visitation in ornamental deutzias (Deutzia spp.), Saxifragaceae sensu lato. J. Apicul. Res. 45(1): 13-19. http://dx.doi. org/10.3896/IBRA.1.45.1.04

Mayfield M.M., Waser N.M., Price M.V. 2001. Exploring the 'Most Effective Pollinator Principle' with Complex Flowers: Bumblebees and Ipomopsis aggregata. Ann. Bot. 88: 591-596.

Mohr N.A., Jay S.C.1990. Nectar production of selected cultivars of Brassica campestris L. and Brassica napus L. J. Apic. Res. 29 (2): 95-100.

Mountain M.F., Day R., Quartley C.H., Go atcher A. 1981. Garden Plants Valuable to Bees. IBRA London, 44 pp.

Ne p i M. 2007. Nectary structure and ultrastructure. [In:] S.W. Nicolson, M. Nepi, E. Pacini (Eds). Nectaries and Nectar. Springer: 138-141.

Ostrowska W. 1981. Obserwacje fenologiczne i pszczelarskie roślin nektaro- i pyłkodajnych w warunkach przyrodniczych Siejnika. Manuscript. (in Polish)

Palmatier E.A. 1943. Some studies on the floral anatomy and morphology of the Saxifragaceae. Ph.D. Dissertation, Cornell University, Ithaca, New York, 73 pp.

Pan C., Zhang L., Wang L., Zhang T.L. 2010. Sex expression and breeding system of Deutzia grandiflora Bge. Ludong Univ. J. (Natural Science Edition) 01.

Rathcke B., Lacey E.P. 1985. Phenological patterns of terrestrial plants. Ann. Rev. Ecol. Syst. 16: 179-214. http://dx.doi.org/10.1146/annurev.ecolsys.16.1.179

Rehder A. 1977. Manual of cultivated trees and shrubs hardy in North America. Macmillan Publishing Co., Inc., New York: 276-284.

Ricciardelli d'Albore G. 1991. Due arbusti poco noti, di elevato interesse apistico: Escallonia langleyensis Veitch. (Escalloniaceae) e Deutzia scabra Thunb. (Hydrangeaceae). L'Apicoltoro moderno, 82: 141-146.

Ruszkowski A. 1969. Food plants of Bombus hypnorum (L.) and its economic importance. Pamiętnik Puławski - Prace IUNG 36: 321-338.

Ruszkowski A., Biliński M. 1968. Bumblebee species on flowers of Saxifragaceae and Rosaceae plants. Pszczel. Zeszyty Nauk. 2 (1-2): 43-66.

Shuel R.W. 1955. Nectar secretion in relation to nitrogen supply, nutritional status and growth of the plant. Can. J. Agric. Sci. 35: 124-138.

Sperling C.D., Lortie CH.J. 2010. The importance of urban backgardens on plant and invertebrate recruitment: a field microcosm experiment. Urban Ecosyst. 13: $223-235$.

Stanisz A. 2006. Przystępny kurs statystyki z zastosowaniem STATISTICA PL Tom.1, StatSoft Polska, Kraków, 529 pp. (in Polish)

Szklanowska K. 1992. Pollen efficiency of some ornamental trees and shrubs from Rosaceae family. Pszczel. Zeszyty Nauk. 36: 65-73.
Tai K., Itino T. 2000. Seasonal pattern of flower utilization in hoverflies (Diptera: Syrphidae) in Kagawa Prefecture, Japan. Technical Bulletin of the Faculty of Agriculture, Kagawa University, 52: 71-77.

Tommasi D., Miro A., Higo H.A., Winston M.L. 2004. Bee diversity and abundance in an urban setting. Can. Entomol. 136: 851-869.

W at a $\mathrm{n}$ a be H. 1998. Soil excavation by deutzia andrenid bee (Andrena prostimias) in a temple garden in Hyogo Prefecture, Japan. App. Soil Ecol. 9: 283-287.

Warakomska Z. 1972. Badania nad wydajnością pyłkową roślin. / Studies on pollen productivity of plants. Pszczel. Zesz. Nauk. 16 (1): 67-106. (in Polish)

Wojcik V.A., Frankie G.W., Thorp R.W., Hern ande z J.L. 2008. Seasonality in bees and their floral resource plants at a constructed urban bee habitat in Berkley, California. J. Kansas Entomol. Soc. 81: 15-28. http://dx.doi.org/10.2317/JKES-701.17.1

Zaikonnikova T.I. 1966. Deizii - dekoratyvnyje kustarniki. Monografia roda Deutzia Thunb. Nauka, Moskva - Leningrad, 140. (in Russian)

\section{Ocena wartości pożytkowej żylistka wrzosowego Deutzia x carnea (Lem.) Rehd. dla pszczół ekosystemów miejskich}

\section{Streszczenie}

W ciągu 4 lat badano fenologię i obfitość kwitnienia oraz produkcję nektaru i pyłku ozdobnych krzewów Deutzia x carnea (Lem.) Rehd. Przeprowadzono obserwacje dotyczące lokalizacji i typu nektarników w LM i SEM. Ponadto monitorowano oblot kwiatów tego gatunku przez pszczoły (Apoidea) żyjące w warunkach miejskich.

Kwitnienie krzewów trwało od początku czerwca do połowy lipca. Liczba kwiatów na roślinie sięgała 47927. Przeciętna długość życia kwiatu wyniosła 5 dni a kwiatostanu - 11 dni. Nektar był wydzielany przez gruczoł o kształcie pierścienia i uwalniany przez szparki ukryte pomiędzy papilami epidermy nektarnika. Dziesięć kwiatów produkowało średnio: 23,94 mg nektaru o koncentracji 39,66\%; 9,91 mg cukrów w nektarze i $16,89 \mathrm{mg}$ pyłku. Szacowana wydajność cukrowa krzewu wyniosła $36,8 \mathrm{~g}$, a jego wydajność pyłkowa $-40 \mathrm{~g}$. Liczba kwiatów na krzewach jak i wielkość pożytku oferowanego owadom różniły się istotnie pomiędzy sezonami wegetacyjnymi, na co miały wpływ zróżnicowane warunki pogodowe. Nektar był głównym pożytkiem zbieranym z kwiatów żylistka wrzosowego przez pszczoły. Wśród nich dominowały pszczoły miodne i trzmiele.

Żylistek wrzosowy można uznać za dobre, uzupełniające źródło pokarmu dla kolonii pszczół na obszarach zurbanizowanych. Czynnikiem ograniczającym jego zastosowanie jest wrażliwość na niskie temperatury i suszę. 